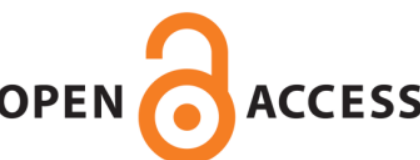

UWS Academic Portal

\title{
Understanding Nepali Nationalism
}

Bhandari, Kalyan

Published in:

Studies in Ethnicity and Nationalism

DOI:

10.1111/sena.12208

Published: 26/01/2017

Document Version

Peer reviewed version

Link to publication on the UWS Academic Portal

Citation for published version (APA):

Bhandari, K. (2017). Understanding Nepali Nationalism. Studies in Ethnicity and Nationalism, 16(3), 416-436. https://doi.org/10.1111/sena.12208

\section{General rights}

Copyright and moral rights for the publications made accessible in the UWS Academic Portal are retained by the authors and/or other copyright owners and it is a condition of accessing publications that users recognise and abide by the legal requirements associated with these rights.

Take down policy

If you believe that this document breaches copyright please contact pure@uws.ac.uk providing details, and we will remove access to the work immediately and investigate your claim. 


\title{
Understanding Nepali nationalism
}

(REVISED APRIL 2016)

\begin{abstract}
This paper explores the foundations of Nepali nationalism and its articulation in contemporary Nepal. It makes informed readings of the historical antecedents of Nepali national identity and argues that Nepali national identity was forged in an attempt to create and maintain a boundary with 'outsiders' - mainly India and China. Data collected through online content analysis of the editorial commentary pages of two Nepali print media, followed by in-depth interviews, show that in the changed political context, the boundary still persists though its narrative has changed. This paper argues that the expression of Nepali nationalism can be understood as the maintenance of this boundary; its forms and articulation shaped by the changing political contexts.
\end{abstract}

Keywords: Nepal, nation, national identity, nationalism, ethnicity, transactional 


\section{Understanding Nepali nationalism}

The 'nation' has remained one of the most significant markers of identity in the modern world. It bears great importance in the articulation of group identity. Different attributes, symbols and images signify the existence of a 'nation', and scholars have defined 'nation' as an 'imagined community' (Anderson 1999); a function of 'modernity' (Gellner 1983), 'bounded entity' (Smith 1991), and an 'invented tradition' (Hobsbawm and Ranger 1983). Most of these concepts place importance on the cultural foundation of a nation and uphold the traditional political sense of a nation as, 'a community of sentiment which would adequately manifest itself in a state of its own' (Weber 1948 cited in Smith 2008: 26). However, the existence of political factors in the expression of nationalism is a stronger element, which is why some scholars consider nationalism to be a political movement that has a cultural dimension (Hutchinson 1999). Acknowledging the contribution of both cultural and political elements in the construction of nationalism, this paper argues that nationalism in Nepal is an expression of its 'objective' differences with the outsider to create and maintain a boundary.

The paper applies a transactional approach to nationalism which focusses on human transactions, that is, on exchanges and relationship between human groups. It exemplifies Barth's (1981) theorisation of ethnicity which views ethnic groups as socially constructed and a form of boundary which is framed through interaction with the 'Others'. Barth (1981) argues that an ethnic group cannot exist in isolation: its formation and continuation is dependent upon their relationship with 'Others', which plays an important role in creating the boundary (Barth 1981). This paper shows that the idea of Nepali 'nation' has developed vis- 
à-vis its interactions with external factors, mainly India and to a lesser extent with China, and as a result, considerable reference is made to external elements in the articulation of Nepali national identity. The Nepali case maintains that national identification is not formed independently but it is strongly informed by the nation's interaction with and perception of the external 'Other'. This paper contributes in understanding the nature of Nepali nationalism in new ways, as the earlier accounts of Nepali nationalism have treated nationalism either as a belief or an ideology that involves an individual identifying with one's nation, and the role of external elements has been largely downplayed.

This study is important and timely as the Nepali state has been continuously modernising through various constitutional changes in the last 60 years. The most revolutionary change took place in 2006 when Nepal abandoned the traditional Hindu monarchy and that has great implications for its 'national' character and the way the new Nepali nation is imagined. Hutchinson (2001) writes that state modernisation ignites competing ethnic traditions with their different versions of community, and it is important for nationalists to legitimise both traditionalism and innovation. Thus, he considers it important for researchers to sensitise the persisting tensions in modern polities between secular national cultures and older religiousbased heritages. Nepal's current situation is ideal for such a study and the tension between the outgoing and incoming polities is high.

This paper begins by providing a commentary on polity that dominated the 'national' narrative of 'Nepaliness' or 'Nepali identity' in recent history. It is important to look into the past because 'sociological explanation is necessarily historical' and we can construct a new world on the basis of what our predecessors have constructed for us (Abrams 1982: 2-3). The latter part is an analysis of public discourse in the editorial commentaries of two Nepali 
newspapers. The study is strongly informed by the new socio-political changes triggered by various internal and external factors in Nepal.

\section{Understanding nations and nationalism}

The concept of 'nation' has been explained in a variety of ways. The study of 'nation' and nationalism can be divided into two important paradigms that dominate scholarship - i) the primordialist approach that supposes that 'nation' is a primordial category, or one founded upon primordial attachments, and ii) the modernist approach that supposes 'nation' to be a modern ideology and movement. There are different variants of both of these approaches. Some primordialists believe that ethnic ties and nationalisms are derived from individual reproductive drives which find their expression in 'nepotistic' behaviour in order to maximise their inclusive fitness (Van den Berghe 1995). For other primordialists the cultural 'givens' of kinship, language, religion, race and territory provide foci for overriding attachments (Shils, 1957; Geertz 1973). However, Smith (2000) believes there are two principal flaws in the primordialist approach: i) they fail to explain how we extrapolate from small kin groups to the much larger and extended communities of ethnie or nation; and ii) they neglect the considerable social and cultural changes that transform the character of the communities which coalesce around them.

In opposition to the primordialists, the modernist paradigm puts forward a more compelling approach to the nation. Modernist explanations have several forms that come associated with the basic idea of modernism: for example socio-cultural, economic, political, ideological and constructionist. The most vocal scholar to propound the modernist approach is Ernest Gellner who in his 1964 book Thought and Change outlined the new theory of nationalism that focussed on the effect of uneven global moderninsation and argued that nationalism is a 
product of industrial society, triggered by the spread of education. Tom Nairn (1981) has further developed Gellner's theory to argue that the uneven development of capitalism caused by imperialism stimulates nationalism. In contrast to Gellner's idea that demands cultural homogeneity, Nairn's idea is based on heterogeneity: it appeals to the people as a whole and identifies the nation with the people.

However, Hobsbawm (1999) challenges the basic premises of Gellner and Nairn by arguing that urbanization and industrialization undermine the condition that breeds ethnically, culturally and linguistically homogeneous groups' desire for nationalism. Nairn and Gellner's economic theory of nationalism is also challengeable because they lay too much emphasis on economic factors and ignore socio-cultural conditions. Nationalism can flourish in all kinds of economic milieu: among rich and poor populations, in stagnant and mobile societies, and in backward and advanced regions (Smith 2000). Thus, Smith (2000) considers that rather than economic or social discontent, it is the ethnic and cultural ties on which a claim to nationalism is based. For Smith (1991: 14-15), the nation signifies a cultural and political bond, uniting in a single political community all who share an historic culture and homeland. Nonetheless, one important flaw in his approach is the question of how a large entity like 'nation' would be based on ethnic bonding and how one can explain the existence of many 'multinational' nations, for example, India.

The above question equally applies to Nepal. According to the 2011 census there are a total of 64 ethnic and 58 caste groups in Nepal (Sharma 2012) and there is a great cultural division within a single group as well. Although ethnicity invokes a sense of rootedness and ancient origins, the existence of many ethnic groups also displays competing conceptions of descent, history, culture and territory (Hutchinson 2001: 83). As such the modernists' proclivity to 
view nations as culturally homogenous and culture as 'value free' (Hutchinson 2001: 83) is not well founded and does not provide a full answer to the question of what binds a nation together - specially for a multi-ethnic country like Nepal.

If we are to consider the relationship between nations and ethnic groups, we must focus on some more essential process, which is the spontaneous construction of ethnic identities as a result of group interaction, a phenomenon which obviously occurs in both the modern and pre-modern world (Conversi 1995). Barth (1981) provides some important insights into this process. He takes the view that ethnic distinctions are maintained and asserted through interaction and interdependence. According to him, ethnic groups are categories of ascription and identification by the actors themselves and the nature and continuity of their self-identity depends on the maintenance of a boundary with the 'Other' or the outsider. According to him, the cultural feature that signal the boundary may change over time and with greater interaction and exposure the cultural characteristics of the members may likewise be transformed, however, there is always a boundary between members and outsiders.

Conversi (1995: 77) calls this approach transactionalism and advances the point that 'nationalism is both a process of border maintenance and creation'. It focuses on human transactions and believes that all forms of interaction need norms and regulations, and borders represent the core of such regulations (Conversi 1995). It argues that borders are essential to all human processes, both at the individual and the social level, and all processes of identity construction are simultaneously border-generating and border-deriving. The approach appreciates the role of internal ascription, i.e, the construction of identity by citizens with the nation (Smith 2009) and also the development of the nation within the larger international community (Tilly 2005). It divulges into the construction of national identity 
within a particular historical context and in relations to each other (Maguire, 2015), for instance, Greenfeld (1995) notes that the definition of the nation is at least in part, determined by the perceived place of the nation in relation to other nations but maintain the notion of the nation as a primarily self-defining group.

Scholars have looked into nationalism from a boundaries perspective with a variety of disciplinary positions such as social psychology, social identity, social movements, creation of inequality and class differences, and cultural practices (Breuilly, 2013; Stephens, 2013; Wimmer, 2013). Most of these have applied the approach as part of nation-building, examining the effects of decolonisation or unmaking of borders on the construction of national identity (see Jackson and Molokotos-Liederman, 2014 for detailed literature on this). However, study that sees ethnicity and nationalism as a tool of boundary creation or as human transactions is given less attention and the case of Nepal is no exception.

Studies on Nepali nationalism was very limited until 1990 (Quigley 1987; Burghart 1984; Rose, 1971; Gaige 1975), however, there has been a profusion of studies on the subject since then, and most of them are dominated by anthropologists and political scientists (Gellner, Czarnecka and Whelpton 2008; Malagodi 2008, 2013; Lawoti and Hangen 2013; Hachhethu 2003; Onta 1996; Hutt 2012; Rademacher 2007; Chalmers 2003). One of the most prominent post-1990 publications is the ethnographic collections which takes a longterm view of the various processes of ethnic and national development and examines the ways that different political regimes have framed and attempted to control castes and ethnic groups (Gellner, Czarnecka and Whelpton 2008, originally published in 1997). This volume tangentially appreciates the role of boundary by dismissing the modernist presupposition that everyone has one and only one nation, or one and only one ethnic attachment and recognises 
that people very often do have multiple and overlapping attachments, and as such they belong to one group for some purposes and other groups for different purposes (also see Gellner 2001).

A follow-up study on the consequences of ethnic mobilisation is presented in a more recent volume by Lawoti and Hangen (2013) that examines the rapid rise in ethnic and nationalist mobilization and conflict since 1990, the dynamics and trajectories of these movements, and their political consequences for Nepal. In the last decade the issue of Nepali nationalism has been discussed from various perspectives: for example the debates on equality or social exclusion and inclusion has strongly challenged the very premise of official Nepali nationalism (see Lawoti 2005; Bhattachan 2009; Giri 2010; Satyal 2011; Guring, Tamang and Turin 2014). Other studies on Nepali nationalism appreciates the role of history, language and culture in shaping how we are viewed and perceived by others (Hall 1996). For example, Hutt (2012) argues that Nepal's adoption of a new national anthem in 2007 reflected a decision to establish a new social and political order that was republican, federal and inclusive of the country's many minority communities. Similarly, Malagodi (2013) examines the complex relationship between law and politics, and emphasizes the role of cultural identity in making institutional choices relating to the framing and implementation of the Nepali Constitution. She also analyses the patterns of legal exclusion that resulted in the growing politicization of identity and the current demand for state-restructuring based on ethnic federalism and group rights. Though the above studies provide a good insight into the discourse of the historically transitional period and are helpful in the contextualised understanding of contemporary national narratives, they all focus on the internal ascription or self-identification. They do not provide complete picture of the formation of national identity because identities are negotiated within a particular historical context (Sahlins 1989) and 
through the categorisation of a nation viz-a-viz other nations (Jenkins 2008): and this study intends to fill this gap.

\section{Methodology}

This paper applies qualitative methodology and relies on both primary and secondary data. The primary data was collected from online content analysis of editorial commentary pages in two Nepali newspapers published in both Nepali and English over a period of 4 months, comprising one month each year from 2010 to 2013. The two newspapers reviewed were: The Kathmandu Post and Nagarik dainik. The analysis of media content is highly relevant because it plays a very important role in the spread and articulation of nationhood (Anderson 1991). The Nepali equivalent term for nationalism is Rastriyata which is used interchangeably to mean nationhood, national identity and sometimes even patriotism. All editorial articles that contained discussion on nationalism and Rastriyata (in Nepali) were selected for analysis. A total of 26 editorial opinion pieces were studied. The choice of editorial articles for analysis was made because media commentators have preferential and active access to media and their opinions plays a big role in forming public discourses, as they are also the preferred actors of news reports and TV programmes (Van Dijk 1995).

After the completion of the second year analysis, the researcher felt a need to interview some commentators for clarification. In-depth interviews were carried out through Skype with the selected 12 contributors to these newspapers through convenience sampling. These interviews covered issues discussed in their commentary and were greatly helpful in clarifying their meaning and context, as interviews are 'historically, politically and contextually bound' (Fontana and Frey 2005: 695). All interviews were transcribed in Word document, colour coded, and themes were identified and analysed. 
The selection of data and the identification of theme in qualitative research has been a contested area and it is often argued that it is subjective and biased. However, we must acknowledge that 'events and behaviours can have different meanings in different cultures or historical eras' (Neuman 2003: 146). The interpretation of the findings presented in this research is strongly informed by the researcher's own background in Nepal and the current socio-political context in Nepal. This is nothing new, but a feature of the qualitative method which applies an interpretive approach, and the researcher's own understanding of the context of the social world he is studying is crucial. However, to overcome any bias that may come associated with the above, secondary data were consulted extensively throughout the research process.

The reason for studying media content was because contemporary societies are mediated through discourse (Wetherell and Tylor 2001). Though discourse is definable in different ways and there are various variants of analysis, for the purpose of this study it is defined as description and interpretation of meaning-making and meaning-understanding (Jaworski and Coupland 1999). This is important when a society has gone through huge social change, because discourse is implicated in expressing people's points of view and value systems, many of which are 'prestructured' in terms of what is 'normal' or 'appropriate' in particular social and institutional settings (Jaworski and Coupland 1999: 6-7). The role of discourse in the construction of national identity is well acknowledged by researchers (see Wodak et al. 1999). Questions may arise as this study is based on a relatively short time period in the fouryear span as previously mentioned. However, the author acknowledges that the purpose of discourse is not to show what absolute truth is, but to see how there are sometimes contradictory truths and different versions of the truth (Rapley 2007: 128). Thus, the findings 
presented here must be understood as one version of the many truths of the research question that drives this study.

\section{Cultural identity and boundary construction in Nepal}

Nepal is one of the oldest nations in South Asia. The country was established in the mid-18th century when a king of Gorkha set out to put together what would become present-day Nepal. For a long period of its history Nepal was in isolation and cut off from the outside world because of internal politics and restrictions imposed by British India. The formal establishment of Nepal's political status came in 1923, when the restrictions on Nepalese diplomatic relationships and trade were finally removed. Nepal's isolation during the 18th and 19th century has a key role to play in the construction of its current 'national' character in two ways. First, it helped the various ethnicities to keep their distinctiveness; as a result Nepal now has an extremely diverse society with more than 100 ethnic and cultural groups (Sharma 2012). Second, this isolation also involved the exception that it was integrated into the capitalist-dominated economy of India (Blaikie, Cameron and Seddon 1980), which had an effect on Nepal's national polity that has always been characterised by its deeply apprehensive attitudes towards India. However, Barth (1981) challenges the view that ethnic identities are developed or fostered in isolation. He argues that ethnic distinctions and cultural differences persist despite inter-ethnic contact and interdependence. The development of Nepali cultural identity is a good example as we will see below.

A real sense of Nepali nationhood only started to evolve after the nineteenth century, when there started greater interaction with external forces, namely India. According to Burghart (1984), the demarcation of the border between British India and Nepal in 1816 sparked the formation of the concept of nation-state in Nepal. Other important episodes that played a 
significant role in the development of nation-state are the designation of Nepali as the official language of Nepal (c.1930), the implicit differentiation of the monarchy from the state (c.1960); and the formation of a culturally unique polity (c. 1960) (Burghart 1984). Burghart's analysis is however, largely concerned with Hindu concepts, values and understanding and has been criticised for presenting nationalism as singular, unchallenged and promoting a dominant worldview (Hangen and Lawoti 2013). However, he is correct in pointing out that the mobilisation of cultural identity in the expression of Nepali nationalism came in the second half of the twentieth century. Interestingly, it did not start in Nepal, but the formation of the cultural sense of Nepal's identity was founded in India by a small group of expatriated Nepalis in British India. Onta (1996) writes, 'while Rana rulers of Nepal and their intellectual bards did not build a historical genealogy for the Nepali nation ...the Nepali proto middle-class actors in British India did exactly that via the self-conscious fostering of the Nepali language and the writing of a bir (brave) history of the Nepali nation' (Onta 1996: 39).

In 1960 the Nepalese King dissolved the elected parliament and introduced Panchayati system, a political system founded on absolute monarchy, which played a lead role in the shaping of modern Nepali national identity that was largely based on the Nepali language and hill identity. Efforts were made to create or invent a mono-cultural sense of 'Nepaliness' on the basis of its 'unique' culture that rested on the philosophy, 'one nation, one language, one dress, one religion' (Subba 2002: 129). Various symbols and icons were invented and aggressively employed to give a distinctive sense of Nepali national identity, and institutions were created to advance this 'nationalist' project. For instance, Nepal Kala Sahistra Pratisthan later renamed as Nepal Rajkiya Pragya Pratisthan or 'The Royal Academy' was established under the king's chairmanship to promote the 'nation's glory' in the name of the 
development of literature, culture, art and knowledge. The academy made a significant contribution in the field of Nepali literature, culture, art and knowledge, though much of this has now been questioned by various linguistic groups.

The use of language as a means to consolidate and assert Nepali identity occurred in conjunction with the emergence of linguistic nationalism in post-independence India. For instance, in India self-governing states were created based on language (Chandra, Mukherjee and Mukherjee 2008). What the king could perhaps not understand was that language can sometimes act as disadvantage because it 'erects a threshold, a tariff, which has to be met if one wishes to participate' (McCrone 2001: 50). In Nepal, the various linguistic groups that constituted more than two thirds of the population of Nepal never felt they were part of the king's narratives.

The Panchayati project was despotic in character though it did not necessarily force people to dissolve their identity. Burghart (1984) writes that the king respected the customs of different countries and registered the fact of this difference by various means. Still, the assertion of a singular Nepali identity had a far reaching effect in forging 'Nepali' identity. Until the eighteenth century, there was no modern nation called Nepal. Though there was some mention of the 'Nepali' nation in some pre-historic texts, this was largely made in reference to the kingdoms of the Kathmandu valley. In the absence of a nation of Nepal, the question of the collective noun 'Nepali', representing the inhabitants of present day Nepal, did not exist. Hamilton (1819: 246), who visited Nepal in 1801, noted that the nobles and soldiers of Gorkha, 'despised the name Nepal'. Burghart (1984) writes that although the British referred to the Nepalese rulers as kings of Nepal, the members of the Shah dynasty prior to the 1930 s thought of themselves as being kings from Gorkha. The Panchayati regime institutionally 
recreated icons, symbols and representations which were mostly derived from Hindu mythologies as to represent the character of Nepaliness or 'Nepalipan' (Rademacher 2007: 128). The regime indirectly forced individuals, groups and communities to personify the symbols in order to become culturally Sanskritised as Nepali. This contributed to the evolutionary process of creating a distinctive Nepali Jati (ethnicity) and helped create Nepali ethnicity as a historical community.

The appropriateness of creating such an identity can be debated, but the invention of a collective noun or 'national' culture is not new. Smith (1986) says that nationalists 'rediscover' historical periods to legitimise their political strategies and to find lessons for the present. In fact there exists a theory of nationalism based on invented tradition. Hobsbawm (1983) provides an historical theory of nationalism that lays emphasis on manufactured historical legacy constructed through 'invented tradition'. He argues that all invented traditions use references to the past, not only to cement group cohesion but also for the legitimisation of action.

Being an accomplished poet and song writer himself, the then Nepalese King Mahendra (1955-1972) was a cultural nationalist. The primary aim of cultural nationalists is to revive what they regard as a distinctive and primordial collective personality which has a name, unique origin, history, culture, homeland and social and political practices (Hutchison 1999). Such revivals are influenced by a particular perception of the threat to its national existence by a powerful neighbour or 'the Other'. In Nepal's case this 'other' was India. Many people would take the view that the threat from India was validated by its annexation of Sikkim, a small kingdom in the Himalayas in the early 1970s (for Sikkim's annexation to India see Datta-Ray 2013; Kazi 1993). But this is not necessarily true. A Nepali psychologist has the 
following to say on Nepalis' perception of India five years before Sikkim was annexed to India:

Nepalis had to reckon with the Indians so long and so often that they are more prone to infer the latters' intents quickly than to observe their overt behaviour. Due to the high degree of intimacy between the two countries through the ages, whatever the Indians do in actual practice is not considered as important as what the Nepalis think the Indians mean (Bhuwan Lal Joshi in Rose 1971: 16).

The Nepali king did try to exploit anti-India feeling and consolidate his power by infusing the cultural sense with the political, and presenting himself as a saviour of Nepalis everywhere. He invited noted literati from Nepali diasporas, particularly in northeast India, to live and settle in Nepal. Such a gesture by the king was important in bringing the political and cultural dimension of Nepali identity closer. One of the strong proponents of that philosophy is the dethroned King Gyanendra. He still tries to claim the monarchy's return is necessary for the existence of the Nepali nation and questions, 'mulukai narahe hami kasari Nepali?, which translates into English: 'how will we remain (Nepali) without the existence of the Nepali nation?' (Shah 2012). According to Pradhan (1982), the word 'Nepali' connotes three different meanings, viz. a language, a citizen of Nepal, and a cultural identity. The king's statement muddles the latter two, to make a claim that the existence of a separate Nepali state is vital for the distinctive identity of Nepalis all over the world. Such muddling is also prevalent at the people's level in various forms (see Maharjan 2012).

The choice of the word Muluk by the king to refer to Nepal or the country also has significance. Muluk has a unique connotation in the Nepali language. The Gorkha rulers, the forefathers of the Nepali kings, claimed their sovereignty by exercising propriety authority 
over their possessions (muluk), and ritual authority within their realm (desa) and various countries (also desa or des) in which the kings' tenants or subjects were natives who claimed certain rights to their land and way of life on the basis of ancestral authority (Burhgart 1984: 103). Each of these three concepts - possessions, realm, and country - specified a different relationship between ruler, land, and people, and each was legitimised with respect to different kinds of authority - propriety, ritual, and ancestral (1984: 103). The boundaries between the three were not always the same and use of the term was to claim cultural propriety over greater territory. The kings, thus, often used Muluk to claim cultural authority not only within Nepal but also transcending the political boundary to reach people in northeast India. Muluk can also mean 'homeland'. The ex-king's reference can be interpreted as meaning that the absence of homeland is tantamount to the loss of Nepali identity, no matter where Nepalis live.

The Panchayati version of state-sponsored nationalism has received much condemnation over the last two and half decades. However, we could also see this from an historical perspective. With the emergence of new nations in the former colonial territories of Asia and Europe, the idea of nation-building and national integration was in vogue. The central premise was that the population of the state, or the citizenry, is progressively welded into a 'nation' in the crucible of a bounded and relatively homogenous transactional and communicative space. That space is defined and delimited by state-wide social, political, economic and cultural institutions and processes (Brubaker 1992: 80). The intervention of the Panchayati state created such homogeneity, and its approach was similar to the 'official nationalism' (Seton-Watson's term) of imperial governments in Europe.

In 1990, Nepal adopted a multiparty parliamentary democracy. The erstwhile state- 
sponsored nationalism became less relevant and cultural homogeneity was strongly disputed., The Tibeto-Burman hill communities challenged the notion of one nation, one identity (Subba 2002: 129) (For a detailed commentary on the politics of ethnic identity since the mid-1990s see Whelpton, Gellner and Pfaff-Czarnecka 2008; Shneiderman 2014; LecomteTilouine 2009). T.B. Subba (2002) endorses the view that the present crisis of Nepali national identity has to do mainly with the earlier attempt to impose a monolithic and homogenous Nepali identity on all Nepalis.

However, people's discontent with the exclusionary polity of the past was very strong and Nepal has now adopted a policy of appeasement to address this. As a result, there are now 40 public holidays, of which 35 exist for celebrating vernacular culture in order to appreciate multiculturalism, though majority of them are still labelled Khas-Arya holidays. Despite having the highest number of public holidays of any country, there is no dedicated 'national' day in Nepal. Though some scholars believe that national days have no real function in a secular age, others take the view that they are commemorative devices in time and place for reinforcing national identity and cannot be overlooked altogether (McCrone and McPherson 2009). Inability to agree on a 'national' day or a 'national culture' is distressing if we consider that nationalism draws on all kinds of sources - myth, legend, religion, history, art, culture, language, literature - to create a cult of the nation (Smith 2008). However, there has been some voice raised lately to reinstate Prithvi Jayanti to mark the birthday of King Prithvi Narayan Shah who founded Nepal. Does this mean the glue that binds the Nepali nation is losing its strength? I believe it would be wrong to think so. However, the manifestation of national identity has definitely changed. Until now we have argued that Nepali identity has been largely shaped by its long interaction with the external elements and has created a distinctive boundary, mainly with India and China. The following section argues that 
contemporary articulation of Nepali national identity is geared towards maintaining this boundary, which now occupies the central position in the narrative of the Nepali nation.

\section{Contemporary public discourse on Nepali nationalism}

Contemporary public discourse on nationalism is largely skewed towards the political end of the nationalism continuum and the external, not internal, factor looms large in the nationalism debate. To some scholars the external factor was superior and crucial (see Rose 1971); however, others have argued that both internal and external elements contributed to shaping Nepali national identity. For example, Burghart (1994) argues that Nepal legitimised the basis of its policy in a way that made sense not only to its own subjects but also to the British and later to the government of India. Similarly, Clarke (1995) argues that the formation of modern ethnic and national identities in Nepal is the result of the successive interplay of two principles of association in civil society, namely 'blood' or kinship, and 'territory'. According to Clarke, this is on the one hand the history of contact with the British Raj and the overall imperial relations from the late eighteenth century, and on the other it is also an account of a transition of local socio-cultural forms in a more traditional Asian hierarchy, with a change to more modern territorial forms of imperial integration.

The association of nationalism with national existence has been the leitmotif in the narrative of Nepali nationalism. It began with the founder king of Gorkha, who in the eighteenth century unified small scattered principalities into present day Nepal and declared, 'this Kingdom is like a traul (yam) between two boulders. Great friendship should be maintained with the Chinese Empire. Friendship should also be maintained with the emperor beyond the southern seas,' a reference to Great Britain, then increasingly exercising power over India (Chaturvedy and Malone, 2012: 288). Since that time, balancing its relations between its 
northern and southern neighbors has remained central to the existence of the Nepali nation. The prolonged exposure to India, whilst remaining in relative isolation from the rest of the world since its formation to the early 1950s, has made Nepal wary of Indian intentions and any serious engagement with India receives strong resistance and is dubbed as antinationalist. This is more with leftist parties. A commentator stated (R7), 'Nepali leftists believe that all political parties except them are Indian agents and status quoists and sometimes this could be their own comrades'. The latest example is when the Maoist Prime Minister signed a Bilateral Investment Promotion and Protection Agreement treaty with India in 2011. He was instantly accused of being an 'Indian agent and anti-nationalist'. However, the interpretation of nationalism for the Maoist PM was, 'we should expand the economic partnership, increase investment to achieve economic prosperity and redefine our external relations; that could be the new base for Nepali nationalism.'(Bhattarai 2011a). Examples are numerous that show the Nepali interpretation of nationalism to be an idea related to the maintenance of external relations to protect its existence and defend its independence. We also see that the economy takes centre stage in these narratives,

We cannot protect our nationalism without achieving economic development and prosperity. When China and India has achieved rapid development, we cannot preserve our nationalism in poverty and underdevelopment. We cannot achieve prosperity without attracting foreign investment.' (Bhattarai 2011b)

A member of a communist party, also a political commentator, took the view that in the twenty-first century it is not possible to remain in isolation and thus the only option available for Nepal is to engage and integrate into the world system. He (R2) further said,

Talking about nationalism, it has been established since the time of King Prithvi Narayan Shah that Nepal should balance its relations with both India and China. 
During the time of bourgeois rule it was believed that Nepal can protect its nationality by acting as a buffer or wall between the two giant nations. In the twenty first century we can now become a thriving bridge between these two nations and protect our nationalism with economic wealth and internal unity. We should construct our nationalism that strengthens our unity internally and become a dynamic bridge connecting the two neighbours.

Material and economic interests can be important, but the traditional idea of nationalism advocates that they do not capture the essence of nationalism in totality (McCrone 2001: 48). Some scholars contradict the above views. For example, Bond, McCrone and Brown (2003) argue that, informed by the past, economic agents mobilise national identity through the process of reiteration, recapture, reinterpretation and repudiation. However, Nepal's geopolitical situation would mean that its vulnerability is not reduced by the economic prosperity of India and China. Scott (2008) argues that with their growing economic capacity, both India and China have 'widening geopolitical horizons' and that 'they both strive to stamp their authority on the same region (2008: 1).

Nepal assumes an important place in a geo-political sense, especially since China took over Tibet in 1950. China has built up its military presence in Tibet and permanent long-distance highways and railway lines have been built - an indication of China's anxiety concerning Tibet (Scott 2008). Nepal's apprehension on China's intent in Nepal has been relatively low until very recently. For example, Joshi wrote in the early 1970s that, '(H)istorically, the Nepalis had so few occasions to become acquainted with the Chinese mind that they are still in the process of observing Chinese overt behaviour vis-à-vis Nepal. In spite of all that has happened between China and India in recent years, Nepali elites are still declined to probe 
into Chinese intents and motives.' (Bhuwan Lal Joshi in Rose, 1971, p. 16). However, this has started to change and Nepal is more aware of China's adventurism in the region's geopolitics. For example, when Maoist Chairman Prachanda backed a Chinese NGOs proposal to develop Lumbini, the birthplace of Lord Buddha, as a premier tourism destination, Nepali press strongly opposed it accusing he was 'hijacking' Lumbini' as a 'China card' to vent his vengeance against India which risk angering India. A prominent Nepali journalist viewed it as a Chinese design to instigate geopolitical race in Nepal (Dixit, 2011). Such opinions show that external elements are important in Nepal's national consciousness and vital for its national interest. A commentator (R8) responded, '(W)ith Lumbini's heritage sites less than $4 \mathrm{~km}$ from the Indian border at its closest, the project hold out the danger of raising a reaction from India and triggering geopolitical competition that would harm Nepali interests'

Many commentators took the view that the Lumbini controversy instigated a new chapter in Nepali nationalism. A commentator (R10) stated, 'the public outcry against China's involvement in Lumbini's development is the evidence of a boundary with its northern neighbour. The China as 'the other' was never expressed so strongly than in the Lumbini case'. There was some common understanding amongst the commentators that the creation of boundary between India and China is a wrong nationalist project though. A respondent (R9) said, 'we should construct our nationalism that strengthens our unity internally and become a dynamic bridge connecting the two neighbours... we should expand our economic partnership, increase investment to achieve economic prosperity and reconfigure our external relations; that could be the new base for Nepali nationalism'.

However, the above examples are useful in understanding the role of external elements in the 
nationalism debate. While many scholars take the view that national identity and nation are complex constructs composed of a number of interrelated components - ethnic, cultural, territorial, economic, legal and political - the Nepali case adds an external element to this list. The contemporary interpretation of Nepali selfhood is defined not only by internal components but there is an important exogenous element which is a key to its independence and existence. This external element remained largely latent after British India governed its polities through the Rana oligarchy. However, the changed political context has brought it to the fore in understanding contemporary Nepali nationhood, exemplifying that nation or national identity is not a static concept. It is constantly changing and is fed by ever-evolving internal and external conditions.

External factors, sovereignty and independence are so rooted in the public discourse of nationalism that the question of how an individual identifies with the nation makes very little sense. At a conference in 2012 organised to deliberate on emerging trends in Nepali nationalism, a young politician, Gagan Thapa, viewed nationalism as being about how one would like to relate with the nation. His idea was dismissed outright by a noted columnist in his article next day, saying such an idea trivialises a serious national issue (Baral 2012). But what Thapa believes in is strongly founded on the idea of 'personal nationalism' by Cohen (1996). Cohen assigns the primacy of actors of their selfhood and self-identity as 'personal nationalism'. That is, one can see the nation by looking at oneself. According to Cohen, by looking at oneself, or one's experience, one's reading of history, perception of the landscape, and reading of literature and music, one can see the nation. It is on sharing personal experiences that sentiment and attachment to the nation is predicated. Thus, self-identity takes a very important role in the construction of nationalism, however such an idea is alien to Nepal. 
Discourse on nationalism is expanding in scope. Breuilly states that the concept of state modernisation provides the key to contextualising nationalism (2001: 51). The narrative that was largely produced by a hill-centred perspective has now been challenged by various ethnic groups and the movements based on ethnicity, language, caste, religion, and regional identity have become increasingly central players in reshaping debates on the definition of the Nepal nation, nationalism and the structure of the Nepali state (Hangen and Lawoti, 2013). These indigenous nationalities and groups are in action demanding their autonomous homeland within the federal Nepal, for example, Newars are demanding a separate Newa province in central Nepal, Madheshis in the southern plains, Limbus in the eastern Nepal, Tharus in the western plains and so on. At the time of writing this paper, the country was witnessing several violent incidents across the southern plains against the proposed 7 state federal setup in the new constitution adopted in September 2015. In the most violent and shocking event, seven security personnel and a child were killed in a clash that ensued between Tharuhat activists and police at Tikapur in the western Kailali district.

The main contention in the new constitution has come from the southern plains often referred to as Terai or Madhesh, the region that borders India and is socio-culturally close to it. For their proximity to India, they are often seen as the 'other' in Nepal. At the time writing this paper the entire Terai region was shut down due to protest against some of the provisions of the new constitution, one of them being the contention over citizenship provisions. Though the last minute changes in the citizenship provisions authorizes women to confer citizenship to their children, on par with men, but women groups and the Madhesi community still argue that further change is necessary lest the provisions make women 'second class' citizens. The main three parties argue that the geopolitical situation, and the large populations of 
neighboring countries India and China, compels them to restrict unwanted population growth (Phuyal, 2015).

The role of India in the recent political change that ended the monarchy was very prominent and since then the southern plains have acquired considerable importance in Nepali polity: national debate is strongly informed by them. In order to test whether the external element is only confined within the dominant mainstream debate, this researcher also looked into the discourse produced by some provincial commentators from the Terai region. A prominent policy think-tank asked a noted columnist to author a 'think paper' to invite debate on a 'new basis of Nepali identity' (Lal 2012: 2). Lal (2012: 57) argues, 'nationality cannot be strengthened without putting foreign policy and relations with close neighbors on a sound footing'. Such a strong assertion of external relations, mainly with India, being instrumental in Nepali nationalism indirectly acknowledges the semi-colonial mindset in Nepal, believed some respondents. However, they also provide insight into the overlapping attachments of Madheshis to India.

This is articulated by another commentator, Pramod Mishra, who mentions two features of Nepali nationalism: external and internal, the former related to the southern neighbour beyond the border and the latter related to southern people within the border. According to Mishra, the people from Terai have yet to be properly integrated into the Nepali national imagination (Mishra 2010a\&b). Though this view is in no way separatist, it could be interpreted as advocating a dilution of nationalism by bringing Nepali identity closer towards that of India, and is questioned in Kathmandu-based discussions. Commentators such as Prashant Jha challenge such questions. He writes: 'Madheshis are Nepalis-but they wish to be Nepalis on terms set by them, not by the Kathmandu establishment (Jha, 2011).' The case 
of new discourse advanced by Jha could best be described a form of dissident narrative. Attwell (2013) argues that Israeli dissidents use alternative national identity discourses to overcome symbolic boundaries. The Madheshi case echoes the case of multiple attachments and shows that they belong to a group that has one kind of identity in relation to some groups and a different sort of identity in relation to other groups (Gellner 2001).

These examples also strengthen the argument that being Nepali can mean different things to different Nepalis (Whelpton 2009). McCrone (2005) argues that there is a 'frame of reference', a prism, through which social, economic and political processes are refracted and the same or similar social attitudes or values will take on different forms of political expression. The Terai 'frame of reference' interprets Nepali identity within a larger Indian cultural unity, which is distinctively different from the people from the hills (see Gaige 1976); though we must also note that the word 'India' itself originally was a cultural/geographical term. The development of such a 'reference', which was very limited until 2008, confirms Pecheux's (1982) theory of how societies are organised through their ideological struggles, and how particular groups will be either more or less privileged in their access to particular discourse network.

It is believed that external threat brings communities together, constructing a common sense of community and plays an important role in arousing powerful nationalist emotions (Ashworth 1991). This is why many countries emphasise a shared history struggle through cultural icons such as heritage, memorials, national days and so on, to engender a sense of collective patriotism. On very few occasions the factor of internal co-existence is mentioned. One example of this was, during the Hindu festival Dashain, Nepal's first President stated, 'the Nepali nationalism that draws its strength from ethnic goodwill, religious and cultural 
tolerance and social unity and territorial integrity is our pride' (Nepal News 2010).

To some commentators the over-emphasis on external factors means that contemporary debate on Nepali nationalism has lost its focus and relevance. A noted scholar has said, '(N)ationalism is about ourselves. We should get rid of this conception that it is about India or China' (Baral 2011). Echoing his views, another respondent opined, 'we should stop condemning these rubbishes...this kind of nationalism needs to be engaged, refuted and moderated in order to shift the focus from anti-India obsession to building people's lives and the country' (R4). True nation building is building people's lives within the state rather than remaining obsessed with your neighbour (Mishra 2010c). However, such views are still very rare and can be said to fall in a minority category in the politically heated atmosphere of Nepal.

\section{Conclusion}

In this study I have shown that the expression of Nepali nationalism is largely intended to maintain a boundary with outsiders. The increased interaction and interdependence with external elements after the 1816 Nepal-India Border Treaty has played an instrumental role in fostering a sense of identity based on 'Nepaliness' or forged Nepali ethnicity. The articulation of Nepali nationalism is largely driven by this distinctive identification in which external elements are key factors. I also showed that the cultural feature that signal the boundary may change, and the cultural characteristics of the members may likewise be transformed, indeed, even the organisational form of the group may change - yet the fact of continuing dichotomisation between members and outsiders allows us to specify the nature of continuity, and investigate the changing cultural form and content (Barth 1981). I have also shown that in the newly evolved political context, there has been a change in the form of 
manifestation; however the boundary still persists in the name of nationalism where India and China are the 'Others'. Such an articulation of Nepali nationalism is original and exemplifies Billig's (2012: 6) idea that nationalism is 'endemic' in nature, shaped by its national specificities.

The Nepali example is useful in understanding the role of external elements in the nationalism debate. While many scholars take the view that national identity and nation are complex constructs composed of a number of interrelated components - ethnic, cultural, territorial, economic, legal and political - the Nepali case adds an external element to this list. The contemporary interpretation of Nepali selfhood is defined not only by internal components but there is also an important exogenous element which is a key to its independence and existence. This external element remained largely latent in bygone eras; however, the changed political context has brought it to the fore in understanding contemporary Nepali nationhood, exemplifying that nation or national identity is not a static concept. It is constantly changing and is fed by ever evolving internal and external conditions.

This study reiterates that nationalism is a multi-dimensional concept. It is the interplay between what we might term formal (state level) and informal (popular) narrations of a nation. It is also about the interaction between cultural and political spheres, the interface between ethnic and civic variants, and the exemplification of internal and external conditions. The question of which of the above assumes a central position is explained by the dominant ideology thesis which states that governments, or ruling elites, will project a message legitimising their position (see Habermas, 1971, 1973). Bourdieu (1977) postulates the existence of so called 'cultural capital' which, according to him, is the key to legitimising the 
exercise of political power to appropriate the control over this capital by any regime.

Understanding nationalism can be important in comprehending the country's international behaviour (Carlson 2011; Dannreuther and Kennedy 2007). The international relations theory suggests that nationalism can shape the state's international relations because what people expect from their state influences its international behaviour (Stullerova 2014). Notwithstanding, whether it is good or bad, Nepal's greater interaction with India means that its identity is often expressed vis-a-vis India and we have seen in this paper that this has created a stronger boundary with India. Thus, India's concern for the people of Terai and other marginalised groups in the new constitution has been opposed by the majority of Nepali people who still associate themselves strongly with Hill identity. Deutsch (1969: 26) argues that when a national minority remains discriminated against for year after year, 'the nation has a prescription for political dynamite', and being a closest neighbour India might be driven by such worries. However, the Nepali government's reaction to Madheshi demands has been driven by peoples' 'perceived' differences with India, and for the majority of Nepalis, Madhesi identity is an extension of Indian identity. Gellner (1983) contends that nationalism would moderate once the transition had been accomplished and societies become affluent (cf. Dannreuther and Kennedy 2007), and until Nepal achieves transition to economic and political stability, external element, namely India, would remain a factor in Nepal's virulent form of nationalism.

However, this study has shown that imposition of identity by the state in Nepal has created a tension between the previous version shaped by 'dominant' national culture and the newly grown ethnic consciousness that discards it. The predominant script of Nepali nationalism that was written from the Panchayati perspective resting on Hindu monarchy has lost its 
traction and the prevailing concept of the nation proposed by the new political regime introduced in the 1990s - anchored in a drive for cultural homogeneity that has been stressed with through the 1950 s - is outmoded. This finding reaffirms Pecheux's (1982) contention that any one particular discourse or discursive formation stands 'at the level of social organisation', in conflict with other discourses. This paper was based on the discourse produced by media commentators; however, it would be interesting to see how the various poly-ethnic groups in Nepal imagine the Nepali nation. Future research could look into this area. 


\section{References}

Abrams, Philip. 1982. Historical Sociology. Somerset: Open Books.

Anderson, Benedict. 1991. Imagined communities: reflections on the origin and spread of nationalism. London: Verso.

Baral, Bhawani. 2012. 'Rastrityatko bahiranga bayaan'. Available at: http://www.nagariknews.com/opinions/98-opinion/37390-2012-02-28-04-59-29.html (accessed 22 November 2012)

Baral, Lok Raj 2011. 'Bharat ra Chin sanga samaduriko sambandha chaina'. Available at: http://www.ekantipur.com/np/2068/8/11/full-story/338919.html (accessed 27 November 2011)

Barth, Fredrik. 1981. 'Ethnic Groups and Boundaries'. In Process and Form in Social Life: Selected Essays of Fredrik Barth:Volume. London: Routledge \& Kegan Paul, 198-227.

Bhattachan, Krishna. Bahadur. 2009. Discourse on Social Exclusion and Inclusion in Nepal: Old Wine in a New Bottle. In Identity and Society: Social Exclusion and Inclusion in Nepal (pp. 11-43), Kathmandu: Social Inclusion Research Fund.

Bhattarai, Baburam. 2011a. 'Janatama Asha ra bishwas jagnu mukhya upalabdhi'. Available at: http://www.ekantipur.com/np/2068/6/15/full-story/336570.html (accessed 2 October 2011)

Bhattarai, Baburam. 2011b. 'Pradhanmantri bhanchan, ma singhadurbarma haraye'. Available at:http://www.nagariknews.com/news-highlights/139-highlights/31815-201110-02-04-32-52.html (accessed 11 December 2011)

Blaikie, Piers, Cameron John and Seddon David. 1980. Nepal in Crisis: growth and stagnation at the periphery. Clarendon Press: Oxford.

Bond, Ross, McCrone, David and Brown Alice. 2003. 'National Identity, and economic development: reiteration, recapture, reinterpretation and repudiation'. Nations and 
Nationalism, 9(3), 371-391.

Bourdieu, Pierre. 1977. Outline of a theory of practice. Cambridge: Cambridge University Press.

Breuilly, John. 2013. The Oxford Handbook of the History of Nationalism. Corby: Oxford University Press.

Breuilly, John. 2001. 'The state and nationalism'. In M. Guibernau and J. Hutchison (Eds.) Understanding nationalism. Cambridge: Polity, 32-52

Brubaker, William Rogers. 1992. Citizenship and nationhood in France and Germany. Cambridge, MA: Harvard University Press.

Burghart, Richard. 1984. 'The formation of the concept of nation-state in Nepal'. Journal of Asian Studies, XLIV(1), 101-125.

Carlson, Allen. 2011. It should not only be about nationalism: China's pluralistic national identity and its implications for Chinese foreign relations. International Studies, 48(3\&4), 223-236.

Chalmers, Rhoderick. 2003. 'We Nepalis': language, literature and the formation of Nepali public sphere in India, 1914-1940'. Unpublished Ph.D. dissertation, School of Oriental and African Studies, University of London.

Chandra, Bipan, Mukherjee Mridula and Mukherjee Aditya. 2008. Indian since independence. New Delhi: Penguin.

Chaturvedy, Rajiv Ranjan and Malone David M 2012. 'A Yam between Two Boulders: Nepal's Foreign Policy Caught between India and China'. In Sebastian von Einsiedel, David M. Malone and Suman Pradhan (Eds.) Nepal in Transition From People's War to Fragile Peace. Cambridge: Cambridge University Press, 287-312.

Clarke, Graham E. 1995. 'Blood and territory as idioms of national identity in Himalayan states'. Kailash, 17(3/4), 89-13. 
Cohen, Anthony P. 1996. 'Personal Nationalism: a Scottish view of some rites, rights, and wrongs'. American Ethnologist, 23(4), 802-815.

Conversi, Daniele. 1995. 'Reassessing current theories of nationalism: nationalism as boundary maintenance and creation'. Nationalism and Ethnic Politics, 1(1), 73-85.

Dannreuther, Roland and Kennedy, James. 2007. The international relations of the ‘transition': Ernest Gellner's social philosophy and political sociology. International Political Sociology, 1, 339-355.

Datta-Ray, Sunanda K. 2013. Smash and Grab: Annexation of Sikkim. New Delhi: Westland. Deutsch, Karl W. 1969. Nationalism and Its Alternatives, New York: Alfred A. Knopf.

Dixit, Kanak Mani 2011. Sangham saranam gachhami. Republica, Available at: http://www.kanakmanidixit.com/?p=430 (Accessed on December 2015)

Fontana, Andrea and Frey James H. 2005. 'The interview: from neutral stance to political involvement'. In Norman K. Denzin and Yvonna S. Lincoln (Eds.), The Sage Handbook of Qualitative Research. London: Sage, 605-727.

Gaige, Frederich H. 1975. Regionalism and national unity in Nepal. Delhi: Vikas Publishing House.

Geertz, Clifford. 1973. Interpretation of cultures: selected essays. London: Fontana Gellner, Ernest. 1983. Nations and nationalism. USA: Cornell University Press.

Gellner, Ernest. 1964. Thought and Change. London: Weidenfield and Nicolson.

Gellner, David, Czarnecka Joanna P and Whelpton John. 2008. Nationalism and ethnicity in Nepal. Vajra Publications: Kathmandu.

Gellner, David. 2001. How should one study ethnicity and nationalism. Contributions to Nepalese Studies, 28(1), 1-10.

Giri, Ram Ashish. 2010. Cultural anarchism: the consequences of privileging languages in Nepal. Journal of Multilingual and Multicultural Development. 31(10, 87-100. 
Greenfeld, Liah. 1995. 'Nationalism in western and eastern Europe compared'. In S.E. Hanson and W. Spohn (Eds.) Can Europe work? Germany \& the reconstruction of postcommunist societies. Seattle: University of Washington Press, 15-23.

Gurung, Om, Tamang, Mukta S. and Turin, Mark. 2014. Perspectives on Social Inclusion and Exclusion in Nepal. Kathmandu: Tribhuwan University Central Department of Sociology/Anthropology

Habermas, Jurgen. 1971. Theorie der Gesellschaft oder Sozialtechnologie: was leistet die Systemforschung, Suhrkamp Frankfurt am Main.

Habermas, Jurgen. 1973. Legitimationsprobleme im Spätkapitalismus, Suhrkamp Frankfurt am Main.

Hachhethu, Krishna and Gellner David N. 2010. 'Nepal: Trajectories of Democracy and Restructuring of the State'. In Paul R. Brass (Ed.) Routledge Handbook of South Asian Politics. London: Routledge, 131-146.

Hachhethu, Krishna. 2003. 'Democracy and nationalism: interface between state and the ethnicity in Nepal'. Contributions to Nepalese Studies, 30(2), 217-252.

Hamilton, Francis Buchanan. 1819. An account of the Kingdom of Nepal. Edinburgh: Archibald Constable.

Hangen, Susan and Lawoti Mahendra. 2013. 'Introduction'. In M. Lawoti and S. Hangen (Eds.) Nationalism and ethnic conflict in Nepal. London: Routledge, 5-34.

Hobsbawm, Eric. 1983. 'Introduction: Inventing traditions'. In Eric Hobsbawm and Terence Ranger (Eds.) The Invention of Tradition. Cambridge: Cambridge University Press, 1-14.

Hobsbawm, Eric. 1999. Nations and Nationalism since 1780. Cambridge: Cambridge University Press.

Hobsbawm, Eric and Ranger Terence. 1983. The Invention of Tradition. Cambridge: 
Cambridge University Press.

Hutchinson, John. 1999. 'Re-interpreting Cultural Nationalism'. Australian Journal of Politics and History, 45(3), 392-407.

Hutchinson, John. 2001. 'Nations and Culture'. In In M. Guibernau and J. Hutchison (Eds.) Understanding nationalism. Cambridge: Polity, 74-96.

Hutt, Michael. 2012. 'Singing new Nepal'. Nations and nationalism, 18(2), 306-325. Jaworski, Adam and Coupland Nikolas. 1999. 'Introduction'. In Adam Jaworski and Nikolas Coupland (Eds.) The discourse reader. London: Routledge, 1-44.

Jha, Prashant. 2011. The nationalism debate. Available at: http://www.ekantipur.com/thekathmandu-post/2011/07/26/oped/the-nationalism-debate/224470.html (accessed 27 September 2011)

Jackson, Jennifer and Molokotos-Leiderman, L. 2014. Nationalism, Ethnicity and Boundaries: Conceptualising and understanding identity through boundary approaches. London: Routledge.

Jenkins, Richard. 1995. 'Nations and nationalism: Towards more open models'. Nations and Nationalism, 1(3), 369-90.

Kazi, Jigme N. 1993. Inside Sikkim: Against the tide. Gangtok: Hill Media Publications

Lal, CK. 2012. To be a Nepalese. Kathmandu: Martin Chautari.

Lawoti, Mahendra. 2005. Towards Democratic Nepal: Inclusive Political Institutions for Multicultural Society. New Delhi: Sage

Lawoti, Mahendra and Hangen Susan. 2013. Nationalism and ethnic conflict in Nepal. London: Routledge.

Lecomte-Tilouine, Marie. 2009. Hindu Kingship, Ethnic Revival, and Maoist Rebellion in Nepal. New Delhi: Oxford University Press.

Maguire, Susan, E. 2015. 'Brother Jonathan and John Bull build a nation: the transactional 
nature of American nationalism in the early nineteenth century'. National Identities. DOI: http://dx.doi.org/10.1080/14608944.2015.1011111

Malagodi, Mara. 2008. 'Forging the Nepali nation through law: A reflection on the use of western legal tools in a Himalayan kingdom'. Studies in Ethnicity and Nationalism, $8(3), 433-452$.

Malagodi, Mara. 2013. Constitutional Nationalism and Legal Exclusion - Equality, Identity Politics and Democracy in Nepal (1990-2007). Delhi: Oxford University Press.

McCrone. David. 2005. 'Cultural capital in an understated nation: the case of Scotland.' The British Journal of Sociology, 56 (1), 65-82),

McCrone, David. 2001. Understanding Scotland, the sociology of a nation - second edition. London: Routledge.

McCrone, David and McPherson Gayle. 2009. National Days: Constructing and mobilising national identity. Basingstoke: Palgrave Macmillan.

Mishra, Pramod. 2010a. 'Critical nationalism'. Available at: http://www.ekantipur.com/2010/12/22/oped/critical-nationalism/326867/ (accessed 9 October 2010)

Mishra, Pramod. 2010b. 'New Nepali nationalism'. Available at:http://www.ekantipur.com/2010/02/03/oped/new-nepali-nationalism/307625/ (accessed 16 March 2010)

Mishra, Pramod. 2010c. 'Anti-India nationalism'. Available at: http://www.ekantipur.com/the-kathmandu-post/2010/08/31/oped/anti-indianationalism/212236/ (accessed 9 October 2010)

Nairn, Tom. 1981. The Break-up of Britain crisis and neo-nationalism. London: Verso Nepalnews. 2010. 'Prez, PM wish Happy Dashain'. Available at: http://www.nepalnews.com/home/index.php/news/19/9903-prez-pm-wish-happy- 
dashain.html (accessed 22 November 2010)

Neuman, W. Lawrence. 2003. Social Research Methods: Qualitative and Quantitative Approaches. London: Pearson Education.

Onta, Pratyoush. 1996. 'Creating a brave Nepali nation in British India: The rhetoric of jati improvement, rediscovery of Bhanubhakta and the writing of bir history'. Studies in Nepali History and Society, 1(1), 37-76.

Pecheux, Michel. 1982. Language, Semantics and Ideology. Basingtoke: Macmillan

Phuyal, Hari, 2015. Nepal's New Constitution: 65 Years in the Making. The diplomat.

Available at: http://thediplomat.com/2015/09/nepals-new-constitution-65-years-in-themaking/ (Accessed 1 November 2015).

Pradhan, Kumar. 1982. Pahilo Pahar. Darjeeling: Shyam Prakashan.

Quigley, Declan. 1987. 'Ethnicity without nationalism: the Newars of Nepal'. European Journal of Sociology, 28(1), 152-170.

Rademacher, Anne. 2007. 'Farewell to the Bagmati Civilisation: Losing Riverscape and Nation in Kathmandu', National Identities, 9(2), 127-142.

Rapley. Tim. 2007. Doing conversation and document analysis. London: Sage.

Rose, Leo E. 1971. Nepal: Strategy for Survival. University of California Press: Berkeley.

Sahlins, Peter. 1989. Boundaries: The making of France and Spain in the Pyrenees.

Berkeley: University of California Press.

Satyal, Poshendra. 2011. Shifting conceptions of social in(justice) in Nepal. New Angle:

Nepal Journal of Social Science and Public Policy, 1(1), 49-64.

Scott, David. 2008. 'The great power 'great game' between India and China: 'The logic of Geography'. Geopolitics, 13 1-26.

Shah, Gyanendra. 2012. Mulukai narahe hami kasari Nepali? Available at: http://onlinekhabar.com/2012/03/134726.html (accessed 16 March 2012) 
Sharma, Pitamber. 2012. 'Some aspects of Nepal's social demography: Update 2011'. Studies in Nepali History and Society, 17(2), December 2012.

Shils, Edward. 1957. 'Primordial, personal, sacred and civil ties'. British Journal of Sociology, 7, 113-45.

Shneiderman, Sara. 2014. 'Reframing Ethnicity: Academic Tropes, Recognition beyond Politics, and Ritualized Action between Nepal and India'. American Anthropologist, $116(2), 279-295$.

Smith, Anthony D. 1986. The Ethnic Origins of Nation. New York: Blackwell.

Smith, Anthony D. 1991. National Identity. Penguin: London .

Smith, Anthony D. 2000. 'Theories of nationalism: Alternative models of nation formation'. In Michael Leifer, (Ed.), Asian Nationalism. London: Routledge, 1-20.

Smith, Anthony D. 2008. The Cultural Foundations of Nations. Michigan: Blackwell Publishing.

Smith, Anthony D. 2009. Ethno-symbolism and nationalism: A cultural approach. New Yorl: Routledge.

Stephens, Angharad Closs (2013) The Persistence of Nationalism: From Imagined Communities to Urban Encounters. New York: Routledge.

Stullerova, Kamila. 2014. In the footsteps of Karl Deutsch: On nationalism, selfdetermination and international relations. International Relations, 28(3), 313-332.

Subba, Tanka B. 2002. 'Nepal and the Indian Nepalis'. In Kanak Mani Dixit and Shastri Ramachandran (Eds.) State of Nepal. Kathmandu: Himal Books, 119-136.

Trevor-Roper, Hugh. 1983. 'The Invention of Tradition: The highland Tradition of Scotland'. In Eric Hobsbawm and Terence Ranger (Eds.), The Invention of Tradition. Cambridge: Cambridge University Press, 15-41.

Tilly, Charles. 2005. Ties that bind... and bound identities, boundaries, and social ties. 
Boulder: Paradigm Press.

Van den Berghe, Pierre. 1995. 'Does race matter?', Nations and Nationalism, 1(3), 357-368

Van Dijk, Teun A. 1995. 'The mass media today: Discourses of domination or Diversity'. The Public, 2(2), 27-45.

Wetherell, Margaret and Tylor Stephanie. 2001. Discursive theory and practice: A reader. London: Sage Publications

Whelpton, John. 2008. 'Political identity in Nepal: State, nation and community'. In David Gellner, Joanna P. Czarnecka,, and John Whelpton (Eds.). Nationalism and ethnicity in Nepal. Vajra Publications: Kathmandu, 39-78.

Whelpton, John, Gellner, David and Pfaff-Czarnecka, Joanna. 2008. 'New Nepal, New Identities: Changes since the Mid 1990s'. In David Gellner, Joanna P. Czarnecka and John Whelpton (Eds.). Nationalism and ethnicity in Nepal. Kathmandu: Vajra Publications, xvii-xlvi.

Wimmer, Andreas. 2013. Ethnic Boundary Making: Institutions, Power, Networks. Oxford Studies in Culture and Politics. New York: Oxford University Press.

Wodak, Ruth, Cillia Rudolf de, Reisigl Martin and Leibhart, Karin. 1999. The discursive construction of national identity. Edinburgh: Edinburgh University Press. 